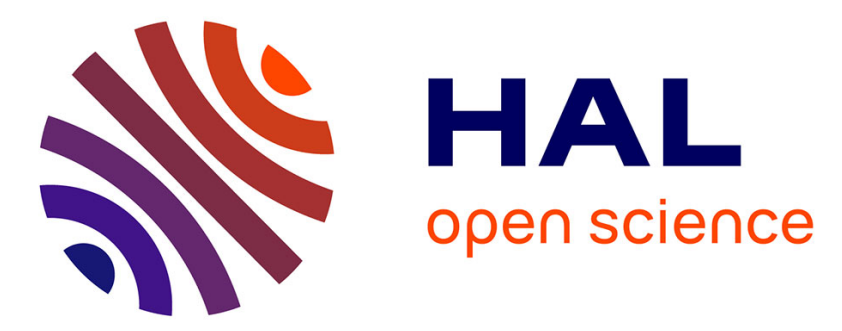

\title{
Compositional and physico-optical characterization of $05 \%$ Al-doped zinc oxide films prepared by chemical spray pyrolysis
}

R Romero, R López-Ibáñez, E A Dalchiele, J R Ramos-Barrado, F Martín, D

Leinen

\section{To cite this version:}

R Romero, R López-Ibáñez, E A Dalchiele, J R Ramos-Barrado, F Martín, et al.. Compositional and physico-optical characterization of $05 \%$ Al-doped zinc oxide films prepared by chemical spray pyrolysis. Journal of Physics D: Applied Physics, 2010, 43 (9), pp.95303. 10.1088/0022-3727/43/9/095303. hal-00569770

\section{HAL Id: hal-00569770 \\ https://hal.science/hal-00569770}

Submitted on 25 Feb 2011

HAL is a multi-disciplinary open access archive for the deposit and dissemination of scientific research documents, whether they are published or not. The documents may come from teaching and research institutions in France or abroad, or from public or private research centers.
L'archive ouverte pluridisciplinaire HAL, est destinée au dépôt et à la diffusion de documents scientifiques de niveau recherche, publiés ou non, émanant des établissements d'enseignement et de recherche français ou étrangers, des laboratoires publics ou privés. 
Compositional and physico-optical characterization of 0 - $5 \%$ Al doped zinc oxide films prepared by chemical spray pyrolysis

R. Romero ${ }^{1}$, R. López-Ibáñez ${ }^{1}$, E.A. Dalchiele ${ }^{2}$, J.R. Ramos-Barrado ${ }^{1}$, F. Martín ${ }^{1}$ and D. Leinen ${ }^{1} *$

${ }^{1}$ Laboratorio de Materiales y Superficie (Unidad Asociada al CSIC), Dpto. Física Aplicada I \& Dpto. Ingeniería Química, Universidad de Málaga, E-29071 Málaga, Spain

${ }^{2}$ Instituto de Física, Facultad de Ingeniería, Universidad de la Republica, Herrera y Reissig 565, C.C. 30, 11000 Montevideo, Uruguay

Highly transparent polycrystalline Al-doped $\mathrm{ZnO}$ thin films were deposited in open atmosphere by chemical spray pyrolysis on fused silica and glass substrates at $623 \mathrm{~K}$. The influence of $\mathrm{Al}$ doping, 0 to $5 \%$, was studied. XPS results revealed a linear relationship between $\mathrm{Al}$ content in the precursor solutions and $\mathrm{Al}$ content in the films. XPS depth profiling showed that any carbon contamination is restricted to the uppermost surface of the films. Optical transmission measurements revealed an increasing amount of dispersion centres as well as a band gap shift to higher values with increasing $\mathrm{Al}$ content in the films. At fixed $\mathrm{Al}$ concentration, the comparison of the absorption coefficient for increasing film thickness showed that the films are very homogeneous, not changing their materials properties like absorption coefficient and band gap.

PACS: 81.15.Rs, 82.80.Pv, 68.53.Dv, 78.66.Fd

Keywords: thin films; chemical synthesis; doping; optical properties. 
Compositional and optical characterization of $\mathrm{Al}$ doped $\mathrm{ZnO}$ films prepared by CSP

\section{Introduction}

Al-doped $\mathrm{ZnO}$ is a multifunctional material. In the form of thin layers, it has been studied for different applications as transparent conductive oxide, infrared mirror, antireflection layer, gas sensor, etc [1]. Al-doped $\mathrm{ZnO}$ films are commonly prepared by sputtering or CVD [2-5]. However, the preparation by chemical spray pyrolysis (CSP) is an interesting alternative due to the potentially very low installation and maintenance cost of the technique. Chemical spraying can be done in open air without the need of special chambers and pumps for a controlled atmosphere or vacuum. Furthermore, CSP can be considered as environmentally friendly since mainly aqueous precursor solutions and air as driving gas are used. Sometimes, depending on the substrate and the material to be deposited, it might be necessary to add small quantities of ethanol (typically $50 \mathrm{ml}$ per liter) and/or acetic acid ( $1-10 \mathrm{ml}$ per liter) to the aqueous precursor solution in order to stabilize the precursor $\left(\sim 10^{-2} \mathrm{M}\right)$ in the aqueous solution by forming stable acylates [6] and to enhance the wettability of the solution to the substrate [7]. Further advantages of spray pyrolysis are: compact or porous films can be obtained depending on the spray conditions; doping can easily be performed by introduction of the doping element into the precursor solution; CSP in open atmosphere can easily be up-scaled to large area deposition [8]. A review on the possibilities of CSP was given by Patil [9]. For CSP, the selection criteria for a precursor in aqueous spray solution is determined by its chemical stability, at least over the period of deposition time, its ease of availability and its cost. This leads directly, in case of $\mathrm{ZnO}$ films, to the selection of zinc acetate and zinc chloride as precursors. Zinc alcoxides could also be used, but have to be stabilized in an aqueous spray solution and are more expensive. Previously, we reported about pure $\mathrm{ZnO}$ films deposited on silicon by spray pyrolysis using zinc acetate precursor. We showed that a maximum growth rate of $15 \mathrm{~nm} / \mathrm{min}$ can be reached for 
substrate temperatures around $543 \mathrm{~K}$ [10] and we studied the electrical properties of those films in detail in the temperature range 223 - $373 \mathrm{~K}$ [11]. We observed different preferred orientations in wurtzite type crystal structure using chloride or acetate zinc precursors and effects on crystal texture with increasing Al doping, as published recently [12]. In the present paper, we study the effect on film composition and physicooptical properties of the films when introducing increasing amounts of $\mathrm{Al}(0-5 \%)$ into the precursor solutions.

\section{Experimental}

In CSP, the precursor solution is sprayed onto the heated substrate. In our lab scale spray station, the substrate is fixed to a metal plate heated using an electrically resistive wiring, at the desired temperature of pyrolysis. During spraying, the substrate is moved underneath the spray nozzle, fixed in position, back and forth at a constant frequency, to obtain a deposit of homogeneous thickness. A stream of compressed air gas through the nozzle, free of oil, is used for the atomization of the solution to very fine droplets. Zinc acetate $\left(\mathrm{Zn}\left(\mathrm{CH}_{3} \mathrm{COO}\right)_{2} \cdot 2 \mathrm{H}_{2} \mathrm{O}\right)$ and zinc chloride $\left(\mathrm{ZnCl}_{2}\right)$ in concentrations of $10^{-2} \mathrm{M}$, fixing the number of metallic atoms in pure water, were the precursors for $\mathrm{ZnO}$. Al doping was performed by adding to the precursor solution aluminium chloride $\left(\mathrm{AlCl}_{3}\right)$ up to $5 \%$ calculated as $\frac{A l}{Z n+A l} \cdot 100 \%$. Substrates were glass and fused silica of size 2 $\mathrm{cm}$ by $2 \mathrm{~cm}$. The injection rate of the precursor solution using a syringe pump was 50 $\mathrm{cm}^{3} / \mathrm{h}$. The air pressure was 1.5 bar, resulting in an air flux through the nozzle of approximately $20 \mathrm{l} / \mathrm{min}$. The nozzle to substrate distance was $20 \mathrm{~cm}$, the substrate temperature $623 \mathrm{~K}\left(350^{\circ} \mathrm{C}\right)$. Samples of various spraying times, i.e. different film thickness, were prepared.

The chemical composition was studied by XPS combined with $4 \mathrm{keV} \mathrm{Ar}^{+}$sputter depth profiling with a PHI 5700 equipment. A standard X-ray source, $15 \mathrm{kV}, 300 \mathrm{~W}, \mathrm{Mg} \mathrm{K} \mathrm{K}_{\alpha}$ 
$(1253.6 \mathrm{eV})$ was used. The pressure in the analysis chamber was about $10^{-7} \mathrm{~Pa}$. The sputter rate at $4 \mathrm{keV} \mathrm{Ar}^{+}$and beam rastering of $3 \times 3 \mathrm{~mm}^{2}$ is assumed to be in oxide material approximately $3 \mathrm{~nm} / \mathrm{min}$ as determined in $\mathrm{Ta}_{2} \mathrm{O}_{5}$ under identical sputter conditions. Binding energies were referenced to the $\mathrm{C} 1 \mathrm{~s}$ peak at $284.8 \mathrm{eV}$ [13]. Atomic concentrations were determined from $\mathrm{C} 1 \mathrm{~s}, \mathrm{Cl} 2 \mathrm{p}, \mathrm{O} 1 \mathrm{~s}, \mathrm{Zn} 2 \mathrm{p}_{3 / 2}$, Si $2 \mathrm{p}$ and $\mathrm{Al} 2 \mathrm{p}$ XPS peak areas using Shirley background subtraction [14] and sensitivity factors provided by the spectrometer manufacturer (Physical Electronics, Eden Prairie, MN).

Optical transmission measurements were made in the UV-VIS range (200 nm - $900 \mathrm{~nm})$ with a Lambda 19 spectrometer from Perkin-Elmer. Spectral hemispherical reflectance measurements were made in the MIR range $(2 \mu \mathrm{m}-17 \mu \mathrm{m})$ with an IFS66 from Bruker with external integrating gold sphere of $20 \mathrm{~cm}$ in diameter. Scanning electron microscopy (SEM) pictures were obtained with a JEOL JSM 5300 apparatus. The electrical resistivity $\rho$ of the films was measured at room temperature on various sites of each sample with a home-made four point probe conductivity tester and calculated after the formula for thin films [15]

$$
\rho=\frac{\pi}{\ln 2} t\left(\frac{V}{I}\right)=4.53 t\left(\frac{V}{I}\right)
$$

where $t$ is the film thickness of the sample, in our case determined from the optical transmission spectra (see below). The resistivity was highest of about $10 \Omega \mathrm{m}$ for the undoped $\mathrm{ZnO}$ films and lowest of about $10^{-2} \Omega \mathrm{m}$ for $3 \% \mathrm{Al}$ doped films.

\section{Results and discussion}

\section{Surface analytical characterization}

The chemical composition at the surface and in-depth was determined by XPS combined with $4 \mathrm{keV} \mathrm{Ar}^{+}$sputtering for $\mathrm{ZnO}: \mathrm{Al}$ thin films obtained from both types of $\mathrm{Zn}$ precursors and for $\mathrm{Al}$ doping between $0 \%$ and $5 \%$. As an example, Figure 1 shows 
the XPS spectra of an $\mathrm{ZnO}: \mathrm{Al}$ film using zinc acetate precursor and $4 \%$ aluminium doping, of its surface and after 1 min $\mathrm{Ar}^{+}$sputtering. A unique $\mathrm{Zn} 2 \mathrm{p}_{3 / 2}$ peak and the principal contribution in the $\mathrm{O} 1 \mathrm{~s}$ peak is observed at $1021.8 \mathrm{eV}$ and $530.3 \mathrm{eV}$ in binding energy, respectively, both typical for $\mathrm{ZnO}$ [13]. Furthermore, we observe in the $\mathrm{O}$ 1s peak another contribution around $531.7 \mathrm{eV}$ which together with the $\mathrm{C} 1 \mathrm{~s}$ peak at $288.7 \mathrm{eV}$ clearly indicates the presence of high amounts of carboxylic species at the film surface [13]. In case of using $\mathrm{Zn}$ chloride precursor, spectra are similar but also chlorine is detected. The $\mathrm{Cl} 2 \mathrm{p}_{3 / 2}$ peak is observed at $198.8 \mathrm{eV}$, a value near to the one documented for $\mathrm{ZnCl}_{2}$ [13]. After sputtering the film surface, the $\mathrm{Cl} 2 \mathrm{p}$ signal persists showing that chlorine is homogeneously distributed with depth at a concentration of approximately 1 at\% (spectra not shown here).

The amount of $\mathrm{Al}$ in the films was determined from the $\mathrm{Al} 2 \mathrm{p}$ peak, centred at $73.8 \mathrm{eV}$. Table 1 shows as an example the XPS atomic concentrations determined for both type of samples, i.e. obtained from $\mathrm{Zn}$ acetate and $\mathrm{Zn}$ chloride precursor. As seen in Figure 1, the intensities of $\mathrm{Zn}$ and $\mathrm{O}$ increase after mild sputtering due to the elimination of the surface contamination in form of aliphatic carbon and carboxylic species. According to Table $1, \mathrm{Zn}$ and $\mathrm{O}$ reach nearly the stoichiometric ratio of $\mathrm{ZnO}$. However, the $\mathrm{Al} 2 \mathrm{p}$ peak is found in more or less the same intensity indicating that $\mathrm{Al}$ is present in excess at the film surface relative to the amount found inside the film. So, there seems to be some segregation of $\mathrm{Al}$ to the film surface during film growth. Figure 1 includes also the $\mathrm{Al}$ KLL Auger peak measured at a kinetic energy of $1388.4 \mathrm{eV}$. The Al 2p and Al KLL energies clearly show that aluminium is incorporated in the film in oxidised state [13]. The modified Auger parameter $\alpha^{\prime}{ }_{\mathrm{Al}}$ determined from the energy position of both peaks is a measure for charge polarisability [16] in the surroundings of $\mathrm{Al}$ atoms in the $\mathrm{ZnO}$ film. The value of $\alpha^{\prime}$ Al is $1462.2 \mathrm{eV}$, slightly higher than in $\mathrm{Al}_{2} \mathrm{O}_{3}$ and suggests that 
aluminium is in a substoichiometric environment relative to $\mathrm{Al}_{2} \mathrm{O}_{3}$ [13]. This can be expected for the $\mathrm{ZnO}$ lattice which offers less $\mathrm{O}$ atoms for each cation compared to the $\mathrm{Al}_{2} \mathrm{O}_{3}$ lattice.

As a quantitative summary, Figure 2 represents the $\mathrm{Al}$ concentration in the films determined with XPS versus the Al concentration in the precursor solution. Both concentrations were calculated as $\frac{A l}{Z n+A l} \cdot 100 \%$. The Al concentrations of various series of film preparation, with and without mild surface etching by $4 \mathrm{keV} \mathrm{Ar}^{+}$ sputtering, are presented. The precursor for $\mathrm{ZnO}$ was $\mathrm{Zn}$ acetate or $\mathrm{Zn}$ chloride. In all cases, the precursor for $\mathrm{Al}$ doping was $\mathrm{AlCl}_{3}$. The principal information of Figure 2 is that we obtain for each series a linear relationship between the $\mathrm{Al}$ concentration in the film and the $\mathrm{Al}$ concentration in the precursor solution. This shows that $\mathrm{Al}$ doping in spray pyrolysis deposited zinc oxide films can easily be controlled. The as-deposited films reveal an excess of aluminium at the film surface whereas shortly sputtered films show a nearly one to one ratio. Further sputtering as used for depth profiling leads to preferential loss of $\mathrm{Al}$ atoms and thus to a constant $\mathrm{Al}$ concentration of about $1 \%$ in the ion bombardment altered layer, independently of the initial Al concentration in the film. This shows that only mild sputtering is applicable for the analysis of the films.

As hydrogen cannot be detected with XPS, IR hemispherical reflectance measurements were performed for both types of samples with and without Al doping. Figure 3 represents the corresponding reflectance spectra between 2 and $4 \mu \mathrm{m}$ in comparison to the fused silica substrate itself. For these measurements the samples were positioned on the sample port of an integrating gold sphere, covering its back with the gold cover plate. Thus we observe nearly total reflectance for that MIR region where fused silica is still transparent unless showing a typical sharp absorption at about $2.74 \mu \mathrm{m}$ due to occlusion of water molecules remaining from silica fusion [17]. Water incorporated in 
the bulk of films, prepared by spray pyrolysis from aqueous precursor solutions, would show a broad absorption due to the $\mathrm{O}-\mathrm{H}$ stretch, from about 2.8 to $3.5 \mu \mathrm{m}$ [18]. The absence of such an absorption feature in Figure 3 shows that no water inclusions are present in the bulk of the films, giving evidence of an effective pyrolysis, curing and densification of the films at a substrate temperature of $623 \mathrm{~K}$.

\section{Optical characterization}

Figure 4 shows the optical transmission spectra of A) undoped $\mathrm{ZnO}$ films and $\mathrm{B}$ ) $3 \% \mathrm{Al}$ doped $\mathrm{ZnO}$ films for increasing film thickness, i.e. increasing spray time, in all cases obtained from the $\mathrm{Zn}$-acetate precursor (films obtained from $\mathrm{Zn}$-chloride precursor have similar transmission spectra). As seen in Figure 4, $\mathrm{ZnO}$ and $\mathrm{ZnO}$ :Al films are highly transparent. The overall transmittance $\tau$ of the films was calculated between $400 \mathrm{~nm}$ and $900 \mathrm{~nm}$ as $\tau=\int \mathrm{T}(\lambda) \mathrm{d} \lambda / \int \mathrm{T}_{\text {glass }}(\lambda) \mathrm{d} \lambda$. For $\mathrm{ZnO}$ films, the transmittance $\tau$ is about 0.92 , nearly independent of the film thickness, whereas for $\mathrm{ZnO}$ :Al films, the transmittance $\tau$ decreases with film thickness from 0.93 to 0.86 . These values of transmittance are in the class of the best obtained for $\mathrm{ZnO}: \mathrm{Al}$ films produced with spray pyrolysis [19-22] and comparable to other highly transparent $\mathrm{ZnO}$ films produced with more expensive physical or chemical techniques[23,24]. The decrease in transmittance at higher film thickness in $\mathrm{ZnO}$ :Al films may be attributed to the increased scattering of photons by crystal defects created by the Al doping $[12,20]$ and a higher surface roughness in ZnO:Al films compared to $\mathrm{ZnO}$ films, as observed by $\mathrm{Li}$ et al. with atomic force microscopy [25]. A qualitative difference between Figure 4 A) and B) is that oscillations in the transmission spectra observed for undoped films, due to an interference effect at the interfaces (air / transparent film) and (transparent film / transparent substrate), are not observed in $\mathrm{ZnO}$ : Al films. It shows that $\mathrm{Al}$ doping leads to scattering of light and thus to the suppression of any optical interference. This may be 
attributed to a higher surface roughness in $\mathrm{ZnO}: \mathrm{Al}$ films [25] and, in particular, the change in crystal growth from highly oriented in $\mathrm{ZnO}$ films to random with smaller average crystallite size in $\mathrm{ZnO}: \mathrm{Al}$ films as observed previously with $\mathrm{XRD}$ [12].

In case of the undoped $\mathrm{ZnO}$ films, the film thickness has been calculated from transmission maxima and minima according to Swanepoel's method [26] given for transparent films on transparent substrates. In order to improve the precision of the method, in particular, when the films are very thin and a transmission maximum or minimum is difficult to determine, a curve has been fitted to each transmission spectrum with thickness $d$ as basic fitting parameter, yielding thus thickness values of more confidence. Table 2 shows the $\mathrm{ZnO}$ film thickness values obtained. The index of refraction has also been calculated according to Swanepoel's method from the envelopes of transmission maxima and minima taking into account the whole set of transmission spectra of $\mathrm{ZnO}$ films on glass represented in Figure 4. For the transparent region, from $900 \mathrm{~nm}$ to $600 \mathrm{~nm}$, the index of refraction is almost constant, increasing weakly from 1.9 to 2.0 whereas in the weak to medium absorbing region, $600 \mathrm{~nm}$ to 400 $\mathrm{nm}$, the index of refraction increases more strongly up to about 2.15 . These values are in agreement to data published on $\mathrm{ZnO}$ and $\mathrm{Al}$-doped $\mathrm{ZnO}$ films studied with ellipsometry [27].

The effect of increasing film thickness in Al doped and undoped films can also be observed in the transmission spectra for energies beyond the $\mathrm{ZnO}$ : $\mathrm{Al}$ absorption edge, not exceeding the absorption edge of the glass substrate. According to Lambert-Beer's law of extinction the transmission shrinks for that energies with increasing film thickness coming to almost zero transmission for thicker films. That is equally observed for $\mathrm{Al}$ doped and undoped $\mathrm{ZnO}$ films although the $\mathrm{ZnO}: \mathrm{Al}$ absorption edge shifts slightly with $\mathrm{Al}$ concentration as discussed below. In that energy region, the 
transmission around $340 \mathrm{~nm}$, equivalent to $3.65 \mathrm{eV}$, (position of the minima of the first derivative of the transmission spectra of $\mathrm{ZnO}$ films; position that shifts slightly, as the absorption edge does, in $\mathrm{ZnO}: \mathrm{Al}$ films with increasing $\mathrm{Al}$ concentration; figure not shown) is directly related to the amount of $\mathrm{ZnO}: \mathrm{Al}$ deposited onto the glass substrate and can thus be used to estimate the film thickness, at least for low film thicknesses, of the Al doped films. To do so, we suppose that the absorption coefficient above the absorption edge of each film does not change considerably between $\mathrm{Al}$ doped and undoped $\mathrm{ZnO}$ films, similarly to what has been observed in $\mathrm{Ga}$ doped $\mathrm{ZnO}$ films up to 5 $\%$ Ga doping [28]. We have calculated the absorption coefficient of $\mathrm{ZnO}$ at $340 \mathrm{~nm}$ from the transmission values of the undoped films of different thickness according to $\alpha$ $=\left[\ln \left(\mathrm{T}_{\text {glass }} / \mathrm{T}\right)\right] / \mathrm{d}$ and indicated in Table 2. We have obtained for this wavelength a mean value of $(154000 \pm 6000) \mathrm{cm}^{-1}$, which is in excellent agreement with absorption coefficient measurements derived from transmission spectra at room temperature of $\mathrm{ZnO}$ single crystal epitaxial films deposited by pulsed laser deposition and film thickness determination with surface profile measurements [29]. It agrees also well with the absorption coefficient observed for energies above the absorption edge in Ga doped $\mathrm{ZnO}$ standing free films [28]. Once, the mean absorption coefficient of the $\mathrm{ZnO}$ films was determined, we have used Lambert-Beer's law to estimate the film thickness of the $3 \% \mathrm{Al}$ doped $\mathrm{ZnO}: \mathrm{Al}$ films. Those values are shown in the last two columns of Table 2. The indicated error was calculated according to error propagation and depends mainly on the mean deviation $\Delta\langle\alpha\rangle$. However, for very low transmission values (thicker films) systematic errors may become important and exceed the indicated error values. In this context, we would like to point out that this method gives the possibility of film thickness estimation for thin films from optical transmission spectra where no interference phenomena are observed. Furthermore, a mean deposition rate of about 3.5 
nm per minute can be deduced from Table 2 for both types of films. However, for very large spray times (>90 min) a reduction in deposition rate can be noticed. In order to confirm the correctness of $\mathrm{ZnO}: \mathrm{Al}$ film thickness estimation, the cross section produced by fracture of the $3 \% \mathrm{Al}$ doped $\mathrm{ZnO}: \mathrm{Al}$ film of 90 min spraying was examined with SEM. As seen in Figure 5, the measured thickness values indicated in the enlarged section of the cross section of the film agree well with the one given in Table 2 and thus show consistency for the aforementioned method of thickness estimation for $\mathrm{ZnO}: \mathrm{Al}$ films within the given error ranges.

Figure 6 shows the absorption coefficient $\alpha$ versus photon energy hv of both series of films, calculated from each transmission spectrum shown in Figure 4 and the corresponding film thickness value given in Table 2. As can be seen, the absorption coefficient curves group together for the $\mathrm{ZnO}$ films (Figure $6 \mathrm{~A}$ )) and for the $3 \% \mathrm{Al}$ doped $\mathrm{ZnO}$ :Al films (Figure $6 \mathrm{~B}$ )), not showing any dependence on the film thickness. This shows that the films are very homogeneous and reproducible. Only for the thinnest $\mathrm{ZnO}$ film (15 min spraying), a higher absorption coefficient was obtained, which might be due to the fact that the interface between film and glass substrate becomes more important for very thin films during their initial stages of film growth by the spray pyrolysis technique. Furthermore, the optical band gap $\mathrm{E}_{\mathrm{g}}$ was determined for each film, fitting a straight line to the absorption edge in $(\alpha h v)^{2}$ versus hv representation and extrapolation to zero absorption. The corresponding band gap values are represented in Figure 7, showing an almost constant value for each series of films independent of the film thickness, unless for the thinnest $\mathrm{ZnO}$ and $3 \% \mathrm{Al}$ doped $\mathrm{ZnO}: \mathrm{Al}$ film. $\mathrm{E}_{\mathrm{g}}$ mean values of $(3.293 \pm 0.004) \mathrm{eV}$ for $\mathrm{ZnO}$ films and $(3.324 \pm 0.004) \mathrm{eV}$ for $3 \% \mathrm{Al}$ doped $\mathrm{ZnO}$ :Al films were calculated, not taking into account the values of the thinnest films (15 min spraying) of $3.244 \mathrm{eV}$ and $3.298 \mathrm{eV}$, respectively. The somewhat lower $\mathrm{E}_{\mathrm{g}}$ 
values obtained for the thinnest films show again that there is an influence of the interface of the substrate to the film on the initial formation of the oxide material during spray deposition.

Finally, comparing films of similar thickness but different $\mathrm{Al}$ concentrations, Figure 8 shows the transmission spectra of $\mathrm{ZnO}$ films, obtained for 90 min spraying ( $\mathrm{Zn}$-acetate precursor) and increasing amounts of $\mathrm{Al}$ doping ( $0 \%$ to $\left.5 \% \mathrm{AlCl}_{3}\right)$. Figure 8 shows again how interference effects are suppressed in the transmission spectra when doping with Al. In addition, we observe a decrease of steepness in the $\mathrm{ZnO}$ band edge and its shift to higher values for increasing $\mathrm{Al}$ concentration. This can be seen more clearly in Figure 9 which represents the corresponding absorption coefficient curves calculated from the transmission spectra of Figure 8. The film thickness values have been determined as explained above, using the transmission of each film above the absorption edge and the absorption coefficient $\alpha=154000 \mathrm{~cm}^{-1}$. Figure 9 shows clearly how the absorption edge shifts to higher energies and broadens with increasing $\mathrm{Al}$ concentration. Both, broadening and blue shift can be explained with the Burstein-Moss effect [30,31]: extra electrons introduced by $\mathrm{Al}$ doping into the semiconductor fill up the bottom of the conduction band making thus available for excitation only sites of higher energy $\mathrm{E}(\mathrm{k})$ which leads to an increase of the optical band gap and to a broadening of the absorption edge through a larger transition distribution of $\mathrm{E}(\mathrm{k})$ at room temperature.

Figure 10 shows the corresponding band gap values obtained for increasing Al concentration by extrapolation to zero absorption, fitting a straight line to the absorption edge in $(\alpha h v)^{2}$ versus $h v$ representation. In case of $0 \%$ and $3 \% \mathrm{Al}$ doping the $\mathrm{E}_{\mathrm{g}}$ mean values aforementioned from Figure 5 are represented. In Figure 10, one can observe a nearly linear increase of the optical band gap with increasing $\mathrm{Al}$ concentration in the 
films. This blue shift of the optical band gap with increasing Al concentration has been reported previously for magnetron sputtered $\mathrm{ZnO}$ :Al films [32] but not studied so far in films obtained with the spray pyrolysis technique and considering such a large range of Al doping $(0-5 \%)$. However, even for a fixed $\mathrm{Al}$ concentration, a large variation of band gap values can be found in the literatures, depending on the type of measurement and on the method of band gap evaluation. In some published work [33], the point of inflection at the band edge of the transmission spectra is directly used for optical band gap estimation. However, this can only be done for the comparison of films of the same film thickness, since the band edge in the transmission spectra is highly sensitive to changes in film thickness.

Table 3 shows a collection of bang gap values $\mathrm{E}_{\mathrm{g}}$ taken from the literature for $\mathrm{ZnO}$ and $\mathrm{Al}$ doped $\mathrm{ZnO}$ films. The method of determining $\mathrm{E}_{\mathrm{g}}$ is also indicated for each value given in Table 3. As one can see, the spread of $\mathrm{E}_{\mathrm{g}}$ values is tremendous but also general tendencies depending on the method can be noticed. The lowest $\mathrm{E}_{\mathrm{g}}$ values have been obtained using transmission measurements, and if available together with reflection measurements, in order to calculate directly the absorption coefficient knowing the film thickness and thus determine the band gap value $\mathrm{E}_{\mathrm{g}}$, as in this work, according to direct type transitions, $(\alpha h v)^{2}=\mathrm{A}\left(\mathrm{E}-\mathrm{E}_{\mathrm{g}}\right)$, for $(\alpha \mathrm{h} v)^{2}=0$. Somewhat higher values can be found in work where ellipsometry data were used and complex dielectric function, refractive index and extinction coefficient were calculated and from the latter the absorption coefficient according to $\alpha=4 \pi \mathrm{k} / \lambda$, and then $\mathrm{E}_{\mathrm{g}}$ as above. A comparison of $\mathrm{E}_{\mathrm{g}}$ values using both methods was given by $\mathrm{Li}$ et al. [27] and, more or less, $0.1 \mathrm{eV}$ higher values were obtained using ellipsometry compared to transmission data in $\mathrm{ZnO}$ and Al-doped $\mathrm{ZnO}$ films (see Table 3). Less difference in $\mathrm{E}_{\mathrm{g}}$ values were obtained for a $\mathrm{ZnO}$ film of $357 \mathrm{~nm}$ thickness studied by Senadim et al. [34] who compared also two 
methods: on the one hand, the absorption coefficient calculated from the transmission spectrum, as explained above, and on the other hand, measuring the reflectance spectrum and calculating, by the use of the Kramers-Kronig transformation, the dielectric function, refractive index and extinction coefficient and from the latter the absorption coefficient.

Comparatively even higher band gap values were obtained looking at the excitonic features in the absorption spectrum which are visible in single crystal $\mathrm{ZnO}$ films even at room temperature due to the high exciton binding energy of about $60 \mathrm{meV}$ in $\mathrm{ZnO}$ [29], compared to the thermal energy $\mathrm{k}_{\mathrm{B}} \mathrm{T}$. Three papers using excitonic features are mentioned in the upper part of Table 3, two of them using transmission spectra data and one of them ellipsometry data. Contrary to what has been mentioned above using the absorption edge for $\mathrm{E}_{\mathrm{g}}$ determination, in this case, the $\mathrm{Eg}$ value obtained from ellipsometry data is lower than the one based on transmission data.

Furthermore, in $\mathrm{Al}$ doped $\mathrm{ZnO}$ films, a shift to very high $\mathrm{E}_{\mathrm{g}}$ values with increasing $\mathrm{Al}$ concentration was reported by Sernelius et al. [32], not comparable, at least according to our knowledge, to band gap shifts observed in other work for similar Al concentration. Besides all aforementioned, the band gap in $\mathrm{ZnO}$ and $\mathrm{Al}$ doped $\mathrm{ZnO}$ films depends on the method of film preparation, the quality of crystalline film which can be obtained by the method, the substrate on which the film is deposited and the temperature of film growth, substrate, and/or post annealing. Various examples can be found in the recollection of data given in Table 3 . Higher substrate temperatures in magnetron sputtered films lead to an increase in crystalline quality and somewhat higher $\mathrm{E}_{\mathrm{g}}$ values [25]. Non crystalline substrates as fused silica lead to lower $E_{g}$ values compared to crystalline substrates, as $\mathrm{C}$ or R plane sapphire [35]. Furthermore, the steepness of the absorption edge was found to be considerably less when using fused silica as substrate 
Compositional and optical characterization of $\mathrm{Al}$ doped $\mathrm{ZnO}$ films prepared by CSP

and was assigned to smaller grain sizes and more defects [35], which is consistent to our observations of absorption edge broadening with increasing $\mathrm{Al}$ concentration as seen in Figure 9.

Finally we would like to mention that we have obtained for our $\mathrm{ZnO}$ films on glass band gap values which are in the upper range of the corresponding ones tabulated in Table 3. This indicates a good crystalline quality of our films. In addition, constant $\mathrm{E}_{\mathrm{g}}$ values for films of different thickness as seen in Figure 7 for $\mathrm{ZnO}$ and $3 \% \mathrm{Al}$ doped $\mathrm{ZnO}: \mathrm{Al}$ films show good reproducibility of our films prepared by spray pyrolysis. However, the optical characterization has also shown that it is important to have films of a certain film thickness when evaluating the effects of $\mathrm{Al}$ doping on the optical properties of the films.

\section{Conclusions}

Highly transparent Al doped zinc oxide films without water inclusions can be obtained by chemical spray pyrolysis spraying aqueous zinc solutions. The amount of Al doping in the films shows to be proportional to the one in the spray solution and thus can be controlled easily. 0 to $5 \% \mathrm{Al}$ doping shifts the $\mathrm{ZnO}$ band gap by about $50 \mathrm{meV}$ to higher values and leads to absorption edge broadening. The absorption coefficient of films of different thickness and Al-doping was calculated from the transmission spectra. The thickness of the $\mathrm{ZnO}$ :Al films was estimated from the absorption of each film using the absorption coefficient of $\mathrm{ZnO}$ films. The thickness estimated for the $\mathrm{ZnO}: \mathrm{Al}$ film of $3 \% \mathrm{Al}$ doping and 90 min spray time agrees well with its thickness observed by SEM. Comparison of the absorption coefficient of films of different spray time, i.e. film thickness, showed good reproducibility in the optical properties of the films.

\section{Acknowledgements}


Compositional and optical characterization of $\mathrm{Al}$ doped $\mathrm{ZnO}$ films prepared by CSP

The authors are grateful to the Spanish Ministry of Education and Science (MEC) for funding (TEC2007-60996) and Consolider Ingenio (CSD2008-00023) and to the Junta de Andalucia through the research group FQM-192. 


\section{References}

1. R.G. Gordon, MRS Bulletin, 25 (2000) 52-57.

2. T. Minami, H. Nanto, S.Takata, Thin Solid Films, 124 (1984) 43.

3. H. Nanto, T. Minami, S. Shooji, S.Takata, J. Appl. Phys., 55 (1984) 1029.

4. J.Hu, R.G. Gordon, J. Appl. Phys., 71 (1992) 880.

5. R.J. Hong, X. Jiang, V. Sittinger, B. Szyszka, T. Höing, G. Bräuer, G. Heide, G.H. Frischat, J. Vac. Sci. Technol. A, 20 (2002) 900.

6. J. Livange, C. Sanchez, M. Henry, S. Doeuff, Solid State Ionics, 32/33 (1989) 633.

7. R. Romero, J.R. Ramos-Barrado, F. Martin and D. Leinen, Surf. Interface. Anal., 36 (2004) 888.

8. R. López Ibáñez, F. Martin, J.R. Ramos-Barrado and D. Leinen, Surf. Coat. Technol., 202 (2008) 2408

9. P. S. Patil, Mat. Chem. Phys., 59 (1999) 185.

10. R. Ayouchi, F. Martin, D. Leinen, J.R. Ramos-Barrado, J. Crystal Growth, 247 (2003) 497.

11. R. Ayouchi, D. Leinen, F. Martin, M. Gabas, E. Dalchiele, J.R. Ramos-Barrado, Thin Solid Films, 426 (2003) 68.

12. R. Romero, D. Leinen, E. Dalchiele, J.R. Ramos-Barrado and F. Martín, Thin Solid Films, 515 (2006) 1942

13. J.F. Moulder, N.F. Stickle, P.E. Sobol, K.D. Bomben, in J. Chastain and R.C. King (Eds), Handbook of X-ray Photoelectron Spectroscopy, Physical Electronics, Eden Prairie, MN, 1995.

14. D.A. Shirley, Phys. Rev. B, 5 (1972) 4709.

15. F.M. Smits, The Bell System Technical Journal, 37 (1958) 711

16. C.D. Wagner, Faraday Discuss. Chem. Soc., 60 (1975) 291

17. G. Socrates, Infrared and Raman characteristic group frequencies. Tables and charts, $3^{\text {rd }}$ edition, John Wiley \& Sons, Chichester, 2001, p. 11

18. R. López, R. Romero, F. Martín, J.R. Ramos-Barrado, D. Leinen, Surf. Interface Anal., 38 (2006) 277

19. A Mosbah, A. Moustaghfir, S. Abed, N Bouhssira, M.S. Aida, E. Tomasella, M. Jacquet, Surf. Coat. Technol., 200 (2005) 293

20. B. Joseph, P.K. Manoj, V.K. Vaidyan, Ceramics International, 32 (2006) 487 
Compositional and optical characterization of $\mathrm{Al}$ doped $\mathrm{ZnO}$ films prepared by CSP

21. M.A. Kaid, A. Ashour, Appl. Surf. Sci., 253 (2007) 2029

22. M.T. Mohammad, A.A. Hashim, M.H. Al-Maamory, Mat. Chem. Phys., 99 (2006) 382

23. E. Senadim, S. Eker, H. Kavak, R. Esen, Solid State Communications, 139 (2006) 479

24. T. Miami, Semicond. Sci. Technol. 20 (2005) S35

25. X.Y. Li, H.J. Li, Z.J Wang, H. Xia, Z.Y. Xiong, J.X. Wang, B.C. Yang, Optics Communications, 282 (2009) 247

26. R. Swanepoel, J. Phys. E, 16 (1983) 1214

27. Q.H. Li, D. Zhu, W. Liu, Y. Liu, X.C. Ma, Appl. Surf. Sci. 254 (2008) 2922

28. J.A. Sanz, J.F. Sánchez-Royo, A. Segura, Superlattices and Microstructures 43 (2008) 362

29. J.F. Muth, R.M. Kolbas, A.K. Sharma, S. Oktyabrsky, J. Narayan, J. Appl. Phys., 85(11) (1999) 7884

30. E. Burstein, Phys. Rev 93 (1954) 632

31. T. Moss, Optical Properties of Semiconductors, Academic Press, New York, 1961

32. B.E. Sernelius, K.F. Berggren, Z.C. Jin, I. Hamberg, C.G. Granquist, Phys. Rev. B, 37 (1988) 10244

33. R.E. Marotti, P. Giorgi, G. Machado, E.A. Dalchiele, Sol. Energy Mater. Sol. Cells, 90 (2006) 2356

34. E. Senadim, S. Eker, H. Kavak, R. Esen, Solid State Communications, 139 (2006) 479

35. V. Srikant, D.R. Clarke, J. Appl. Phys, 81 (1997) 6357

36. W.Y. Liang, A.D. Yoffe, Phys. Rev. Lett., 20 (1968) 59

37. P.L. Washington, H.C. Ong, J.Y. Dai, R.P.H. Chang, Appl. Phys. Lett., 72 (1998) 3261 
Compositional and optical characterization of $\mathrm{Al}$ doped $\mathrm{ZnO}$ films prepared by $\mathrm{CSP}$

Table 1: XPS atomic concentrations of $\mathrm{ZnO}: \mathrm{Al}$ films using $\mathrm{Zn}$ acetate or $\mathrm{Zn}$ chloride precursors. $\mathrm{Zn} / \mathrm{O}$ ratio is given after surface etching.

\begin{tabular}{|l|c|c|c|c|c|c|c|}
\hline Sample & $\begin{array}{c}4 \mathrm{keV} \mathrm{Ar}^{+} \\
\text {sputter time / }\end{array}$ & $\mathrm{Zn}$ & $\mathrm{O}$ & $\mathrm{Al}$ & $\mathrm{C}$ & $\mathrm{Cl}$ & $\mathrm{Zn} / \mathrm{O}$ \\
& $\mathrm{min}$ & & & & & & \\
\hline ZnO:Al Film from Fig. 1 & 0 & 11.1 & 32.7 & 2.2 & 54.0 & - & - \\
\cline { 2 - 9 } Zn acetate; 4 \% Al & 1 & 41.9 & 50.7 & 2.5 & 4.9 & - & 0.83 \\
\hline ZnO:Al Film & 0 & 11.9 & 34.7 & 2.3 & 50.5 & 0.6 & - \\
\hline \multirow{2}{*}{ Zn chloride; 3.5 \% Al } & 1 & 46.0 & 50.4 & 2.9 & - & 0.7 & 0.85 \\
\hline
\end{tabular}


Table 2: A) Absorption coefficient $\alpha$ calculated at $340 \mathrm{~nm}$ of $\mathrm{ZnO}$ films on glass for increasing spray time (film thickness $d$ determined after Swanepoel [26]). The mean value $\langle\alpha\rangle$ for $\mathrm{ZnO}$ films is given below. B) Film thicknesses $d$ and estimated error $\Delta d$ of $\mathrm{ZnO}: \mathrm{Al}(3 \% \mathrm{Al})$ films for increasing spray times, calculated after Lambert-Beer's law of extinction as given below using the mean value $\langle\alpha\rangle$. T are the measured transmission values of $\mathrm{ZnO}$ and $\mathrm{ZnO}: \mathrm{Al}$ films at $340 \mathrm{~nm}$ and $335 \mathrm{~nm}$, respectively; $\mathrm{T}_{\text {glass }}$ is 0.87 and 0.86 , respectively.

\begin{tabular}{|l|c|c|c|c|c|c|}
\hline \multicolumn{5}{|c|}{ A) ZnO } & \multicolumn{3}{c|}{ B) ZnO:Al3\% } \\
\hline $\mathrm{t} / \mathrm{min}$ & $\mathrm{T}$ & $\mathrm{d} / \mathrm{nm}$ & $\alpha / \mathrm{nm}^{-1}$ & $\mathrm{~T}$ & $\mathrm{~d} / \mathrm{nm}$ & $\Delta \mathrm{d} / \mathrm{nm}$ \\
\hline 15 & 0.3960 & 40 & 0.01900 & 0.4276 & 45 & 5 \\
\hline 30 & 0.2051 & 90 & 0.01606 & 0.2487 & 80 & 10 \\
\hline 45 & 0.1042 & 132 & 0.01607 & 0.0797 & 150 & 10 \\
\hline 60 & 0.0525 & 176 & 0.01595 & 0.0365 & 200 & 10 \\
\hline 75 & 0.0196 & 247 & 0.01536 & 0.0203 & 240 & 10 \\
\hline 90 & 0.0061 & 334 & 0.01485 & 0.0105 & 280 & 20 \\
\hline 105 & 0.0042 & 361 & 0.01476 & 0.0099 & 290 & 20 \\
\hline 120 & 0.0037 & 368 & 0.01481 & 0.0084 & 300 & 20 \\
\hline
\end{tabular}


Table 3: Band gap values from the literature for $\mathrm{ZnO}$ and $\mathrm{Al}$-doped $\mathrm{ZnO}$ films. Indicated is also the type of substrate, the manner of film preparation, the measurement / method used for band gap determination and the $\mathrm{Al}$ concentration.

\begin{tabular}{|c|c|c|c|}
\hline film / preparation / author (year) & method & Al conc. & $\mathrm{E}_{\mathrm{g}}(\mathbf{e V})$ \\
\hline $\begin{array}{l}\text { ZnO single crystal film / PVD / Liang } \\
\text { and Hoffe (1968) [36] }\end{array}$ & $\mathrm{T} \rightarrow \alpha$ (excitonic feature) & 0 & $\begin{array}{l}3.445(4.2 \mathrm{~K}) \\
3.40\end{array}$ \\
\hline $\begin{array}{l}\text { ZnO single crystal on sapphire / PLD } \\
\text { / Muth et al. (1999) [29] }\end{array}$ & $\mathrm{T} \rightarrow \alpha$ (excitonic feature) & 0 & $\begin{array}{l}3.455(77 \mathrm{~K}) \\
3.40\end{array}$ \\
\hline $\begin{array}{l}\text { ZnO single crystal on sapphire / PLD } \\
\text { / Washington (1998) [37] }\end{array}$ & $\varepsilon \rightarrow \alpha$ (excitonic feature) & 0 & $3.372(295 \mathrm{~K})$ \\
\hline $\begin{array}{l}\mathrm{Al}: \mathrm{ZnO} \text { on } \mathrm{Si}(100) / \mathrm{RF}(\mathrm{ZnO})+ \\
\mathrm{DC}(\mathrm{Al}) \text { magnetron sputtering }\left(800^{\circ} \mathrm{C}\right. \\
\text { post annealing }) / \mathrm{Li} \text { et al. }(2008)[27]\end{array}$ & $\begin{array}{l}\mathrm{T} \rightarrow \alpha \\
\varepsilon \rightarrow \alpha\end{array}$ & 0 & $\begin{array}{l}3.26(\mathrm{~T}) \\
3.34(\varepsilon) \\
3.32(\mathrm{~T}) \\
3.45(\varepsilon)\end{array}$ \\
\hline $\begin{array}{l}\mathrm{Al}: \mathrm{ZnO} \text { on } \mathrm{CaF}_{2} / \mathrm{RF}(\mathrm{ZnO})+ \\
\mathrm{DC}(\mathrm{Al}) \text { magnetron sputtering / } \\
\text { Sernelius et al. (1988) [32] }\end{array}$ & $\begin{array}{l}\mathrm{T}+\mathrm{R} \rightarrow \text { dielectric } \\
\text { function (Fresnel } \\
\text { equations) } \rightarrow \alpha\end{array}$ & $\begin{array}{l}0 \\
2.14(\text { at } \%)\end{array}$ & $\begin{array}{l}3.40(\mathrm{~d} \alpha / \mathrm{dE}) \\
3.90(\mathrm{~d} \alpha / \mathrm{dE})\end{array}$ \\
\hline $\begin{array}{l}\text { ZnO on sapphire and fused silica / } \\
\mathrm{PLD} \text { at } 600^{\circ} \mathrm{C} / \text { Srikant et al. (1997) } \\
\text { [35] }\end{array}$ & $\mathrm{T} \rightarrow \alpha$ & 0 & $\begin{array}{l}3.29 \text { (0001) } \\
3.32(1102) \\
3.26 \text { (f.s.) } \\
3.28 \text { (f.s.) p.a. } 800^{\circ} \mathrm{C}\end{array}$ \\
\hline $\begin{array}{l}\mathrm{ZnO} \text { on glass / PFCVAD / Senadim } \\
\text { et al. (2006) [34] }\end{array}$ & $\begin{array}{l}\mathrm{T} \rightarrow \alpha, \\
\mathrm{R} \rightarrow \text { dielectric function } \\
(\text { Kramers-Kronig), n, } \mathrm{k} \\
\rightarrow \alpha\end{array}$ & 0 & $\begin{array}{l}3.22 \\
3.24\end{array}$ \\
\hline $\begin{array}{l}\mathrm{Al}: \mathrm{ZnO} \text { on glass / DC magnetron } \\
\text { sputtering (substrate temperature } 25- \\
\left.300^{\circ} \mathrm{C}\right) / \mathrm{Li} \text { et al. }(2009)[25]\end{array}$ & $\mathrm{T}+\mathrm{R} \rightarrow \alpha$ & 0 & $\begin{array}{l}3.25-3.35 \\
\left(25-300^{\circ} \mathrm{C}\right) \\
3.42-3.46 \\
\end{array}$ \\
\hline $\begin{array}{l}\mathrm{Al}: \mathrm{ZnO} \text { on glass / spray pyrolysis } \\
\left(450^{\circ} \mathrm{C} ; 0.1 \mathrm{M} \text { zinc acetate aqueous }\right) / \\
\mathrm{J} \text { / }\end{array}$ & $\mathrm{T} \rightarrow \alpha$ & $\begin{array}{l}0 \\
1.6 \\
(\mathrm{Al} / \mathrm{Zn} \%) \\
\end{array}$ & $\begin{array}{l}3.24 \\
3.28\end{array}$ \\
\hline
\end{tabular}

$\mathrm{T}=$ transmission, $\mathrm{R}=$ reflection, $\varepsilon=$ ellipsometry, $\alpha=$ absoprtion, $\mathrm{p} . \mathrm{a} .=$ post annealed 


\section{Figure Captions:}

Figure 1: XPS spectra of an as-deposited $\mathrm{ZnO}: \mathrm{Al}$ film on fused silica substrate and after 1 min $4 \mathrm{keV} \mathrm{Ar}^{+}$surface cleaning. Precursors: Zn-acetate $+4 \%$ Al-chloride. Auger peak Al KLL in kinetic energy representation.

Figure 2: Al concentration in the film determined with XPS versus Al concentration in the precursor solution, both as $100 \% \cdot \mathrm{Al} /(\mathrm{Al}+\mathrm{Zn})$, of various series of film preparation with and without $4 \mathrm{keV} \mathrm{Ar}^{+}$surface etching. Straight lines are linear fits to the data points of each series.

Figure 3: IR hemispherical reflectance spectra of pure and $3 \% \mathrm{Al}$ doped $\mathrm{ZnO}$ films from acetate or chloride precursor, deposited on fused silica. The reflectance spectrum of the substrate is also represented for comparison.

Figure 4: Optical transmission spectra of A) undoped $\mathrm{ZnO}$ films on glass substrate and B) 3\% $\mathrm{Al}$ doped $\mathrm{ZnO}$ films on glass substrate, for increasing spray time deposition (in minutes).

Figure 5: SEM image of the cross section produced by fracture of the $3 \% \mathrm{Al}$ doped $\mathrm{ZnO}: \mathrm{Al}$ film of $30 \mathrm{~min}$ spraying onto glass substrate (its transmission spectrum is shown in Figure 4 B)). For the enlarged area of the film cross section, three values (nm) of observed film thickness are indicated.

Figure 6: Absorption coefficient curves calculated from the transmission spectra shown in Figure 4 and film thickness values given in Table 2. A) undoped $\mathrm{ZnO}$ films on glass and $\mathrm{B}) 3 \% \mathrm{Al}$ doped $\mathrm{ZnO}$ films on glass.

Figure 7: Optical band gap values $\mathrm{E}_{\mathrm{g}}$ versus film thickness of the undoped $\mathrm{ZnO}$ films and the $3 \% \mathrm{Al}$ doped $\mathrm{ZnO}$ films.

Figure 8: Optical transmission spectra of $\mathrm{Al}$ doped $\mathrm{ZnO}$ films on glass substrate for increasing $\mathrm{Al}$ concentration. Estimated film thickness: $334 \mathrm{~nm}(0 \% \mathrm{Al}), 268 \mathrm{~nm}(1 \%$ $\mathrm{Al}), 252 \mathrm{~nm}(2 \% \mathrm{Al}), 285 \mathrm{~nm}(3 \% \mathrm{Al}), 253 \mathrm{~nm}(4 \% \mathrm{Al})$ and $234 \mathrm{~nm}(5 \% \mathrm{Al})$.

Figure 9: Absorption coefficient curves calculated from the transmission spectra of Figure 8 of $0-5 \% \mathrm{Al}$ doped $\mathrm{ZnO}$ films.

Figure 10: Optical band gap values $\mathrm{E}_{\mathrm{g}}$ versus $\mathrm{Al}$ concentration $(\mathrm{x})$ in the $\mathrm{Al}$ doped $\mathrm{ZnO}$ films. 

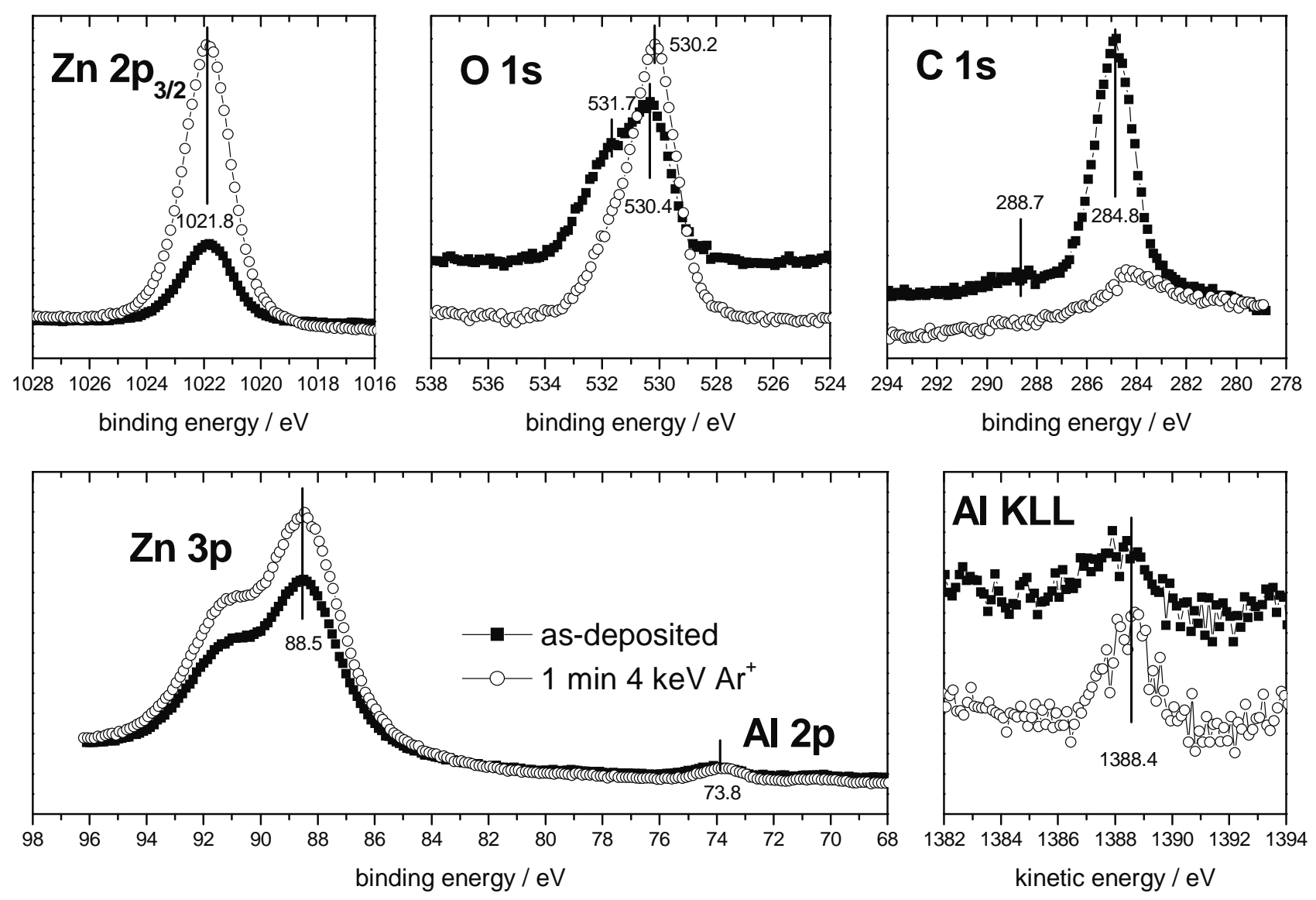


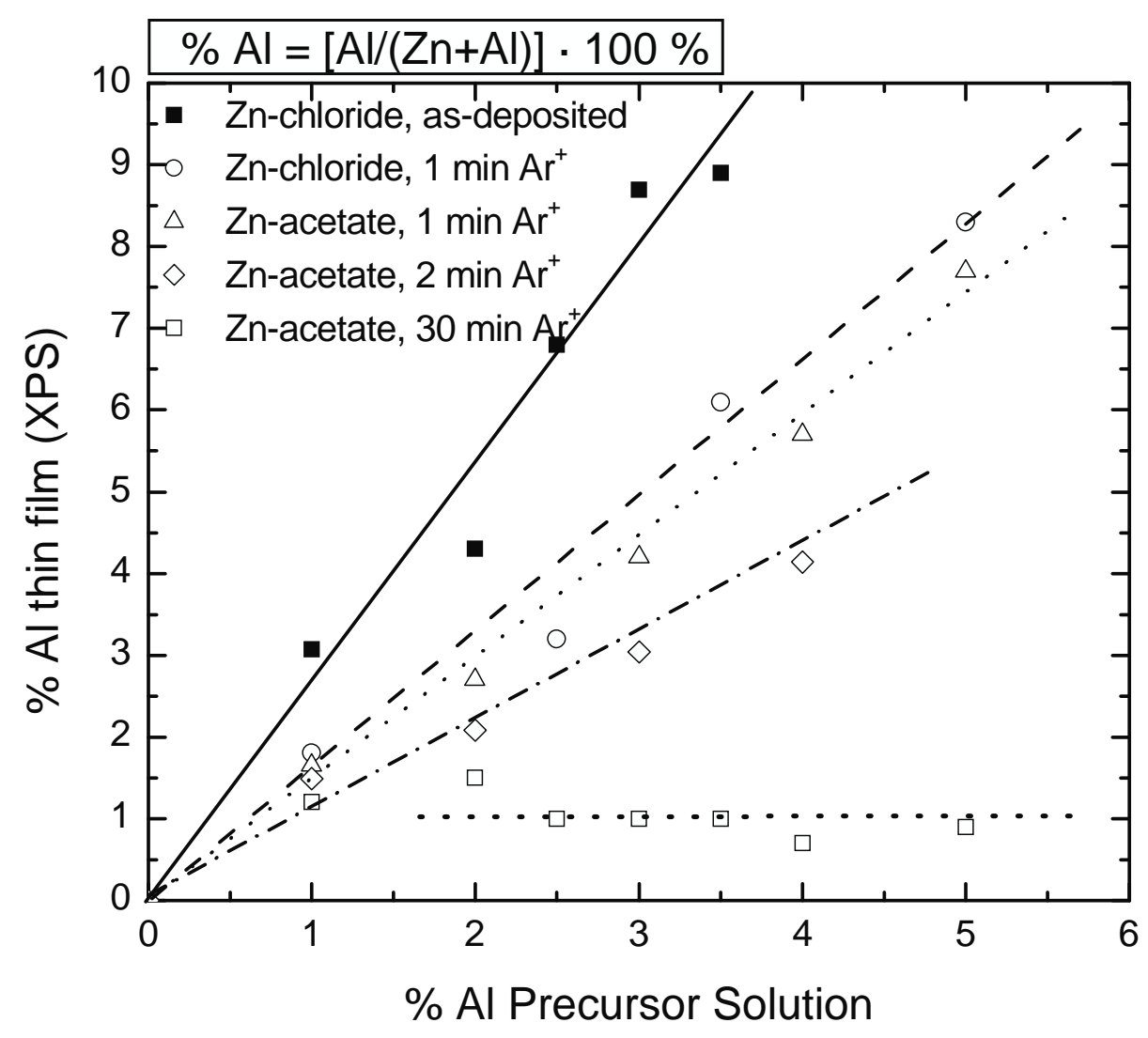

2 


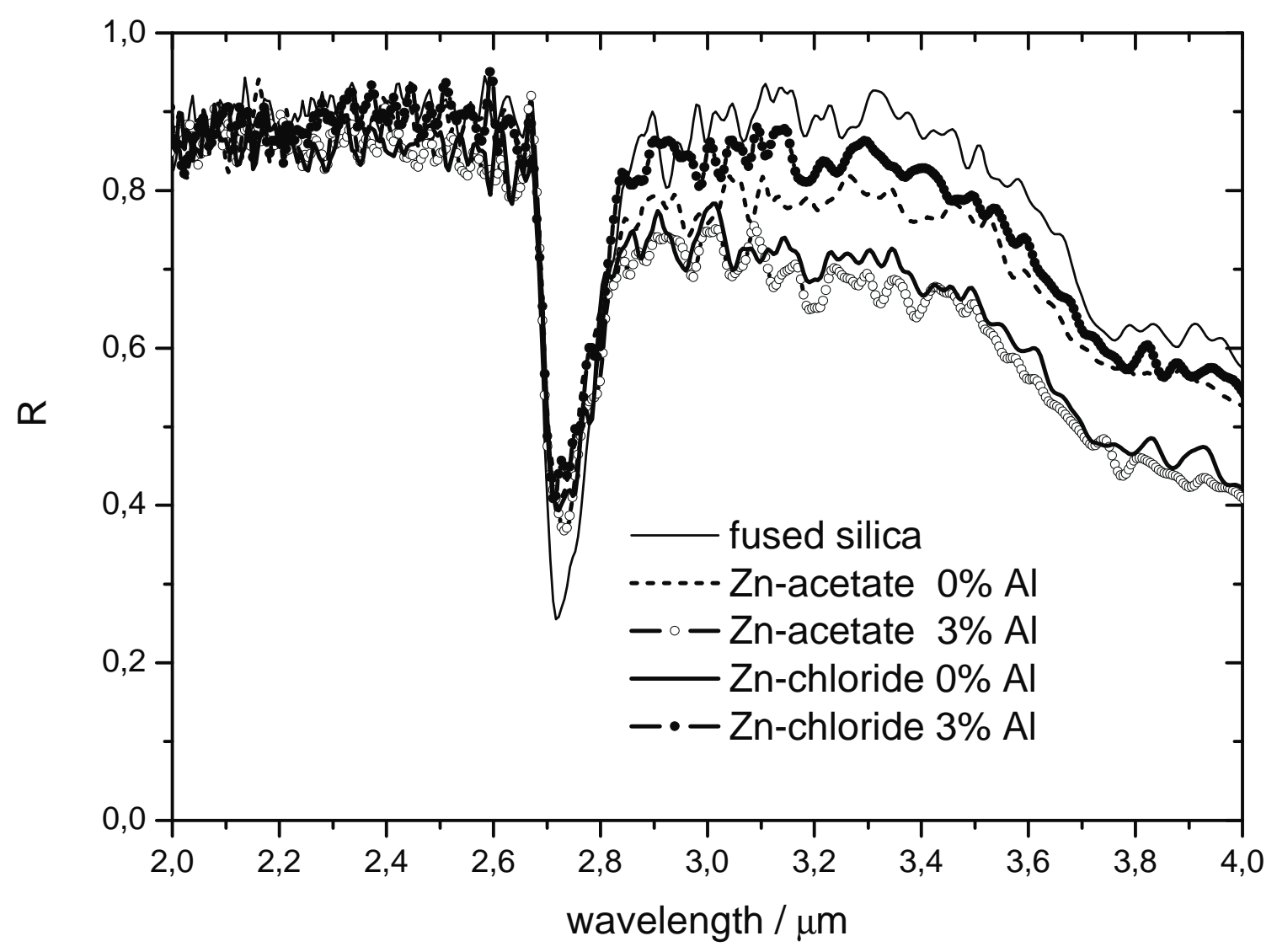



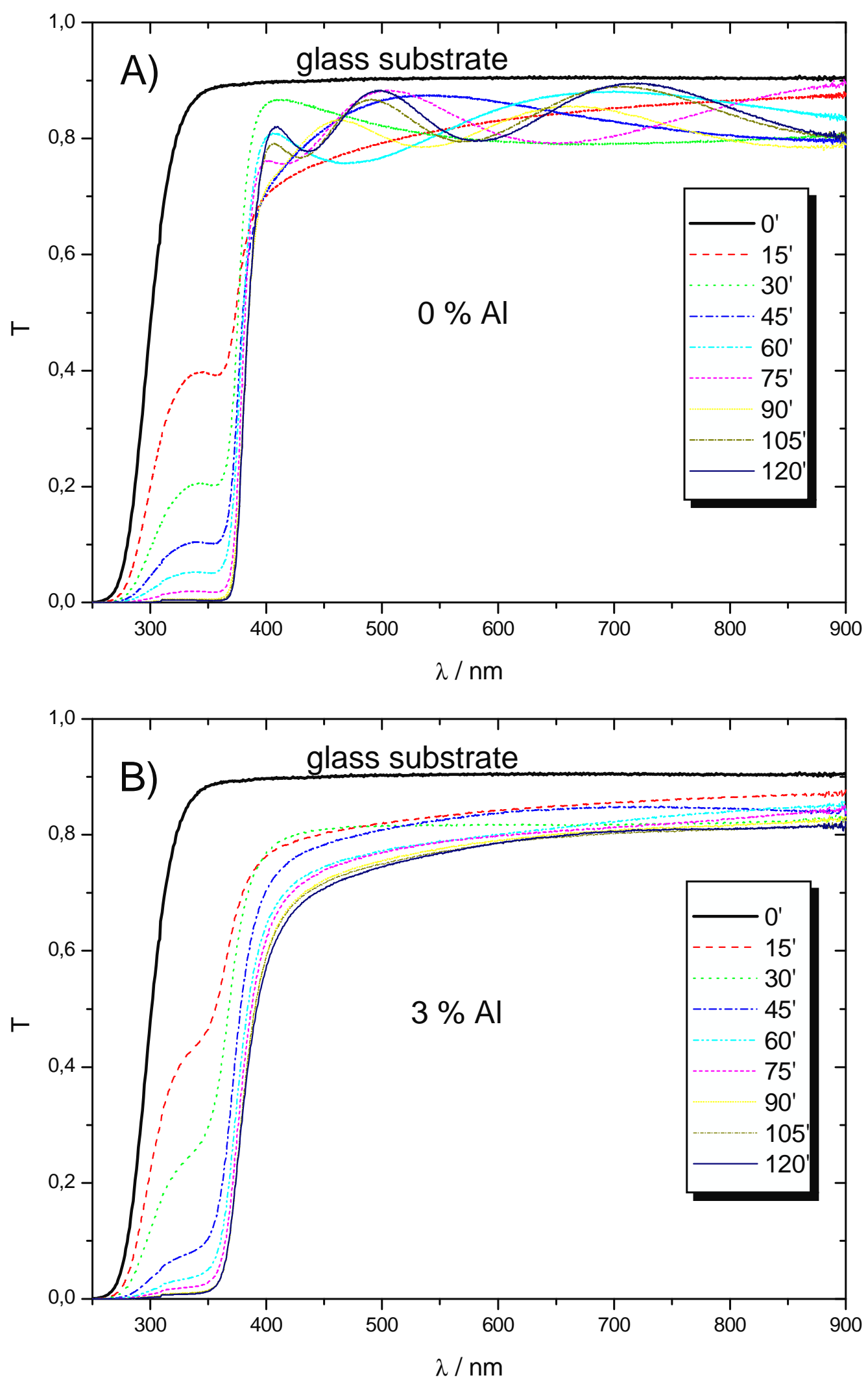
Compositional and optical characterization of $\mathrm{Al}$ doped $\mathrm{ZnO}$ films prepared by CSP

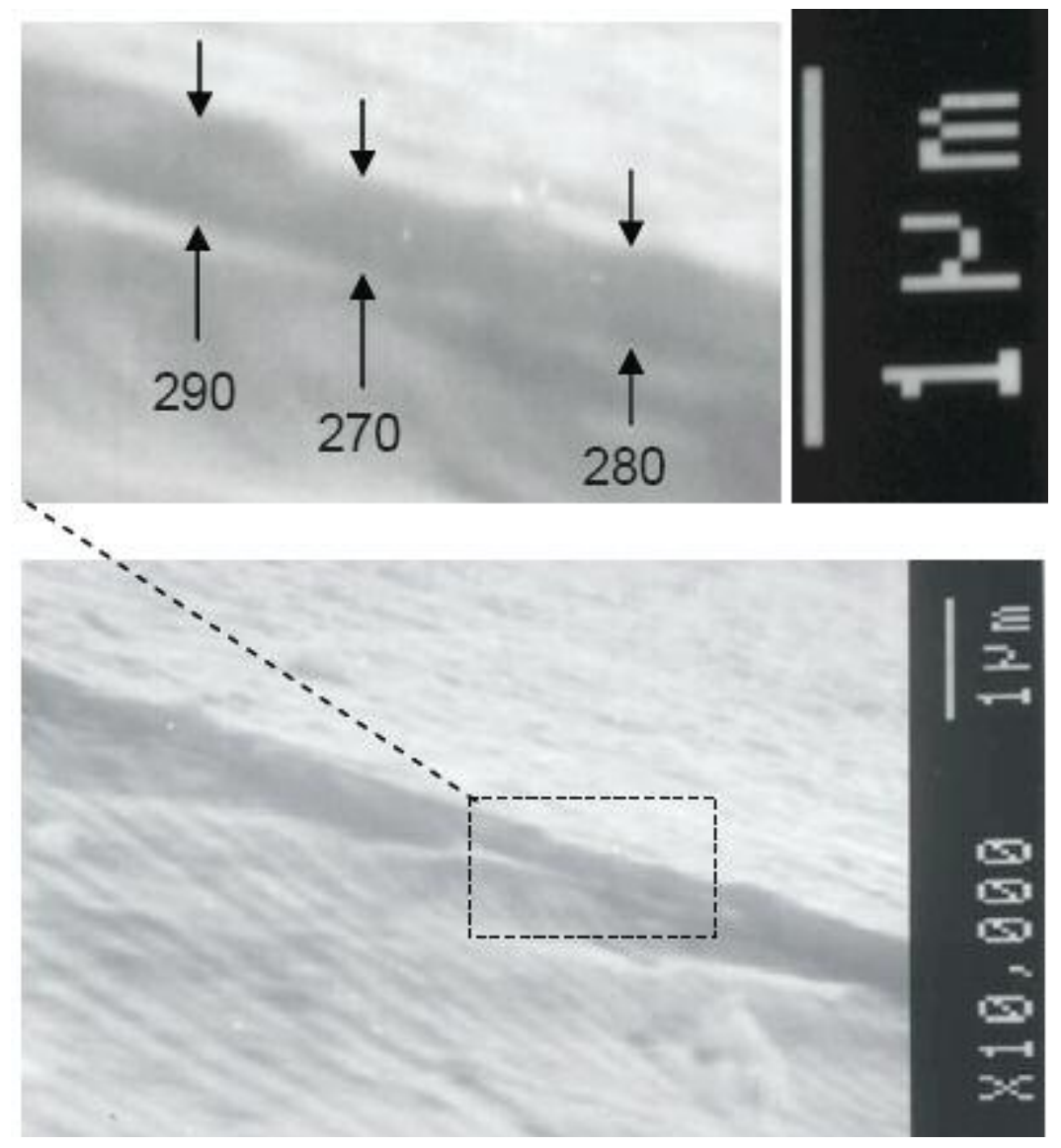

5 

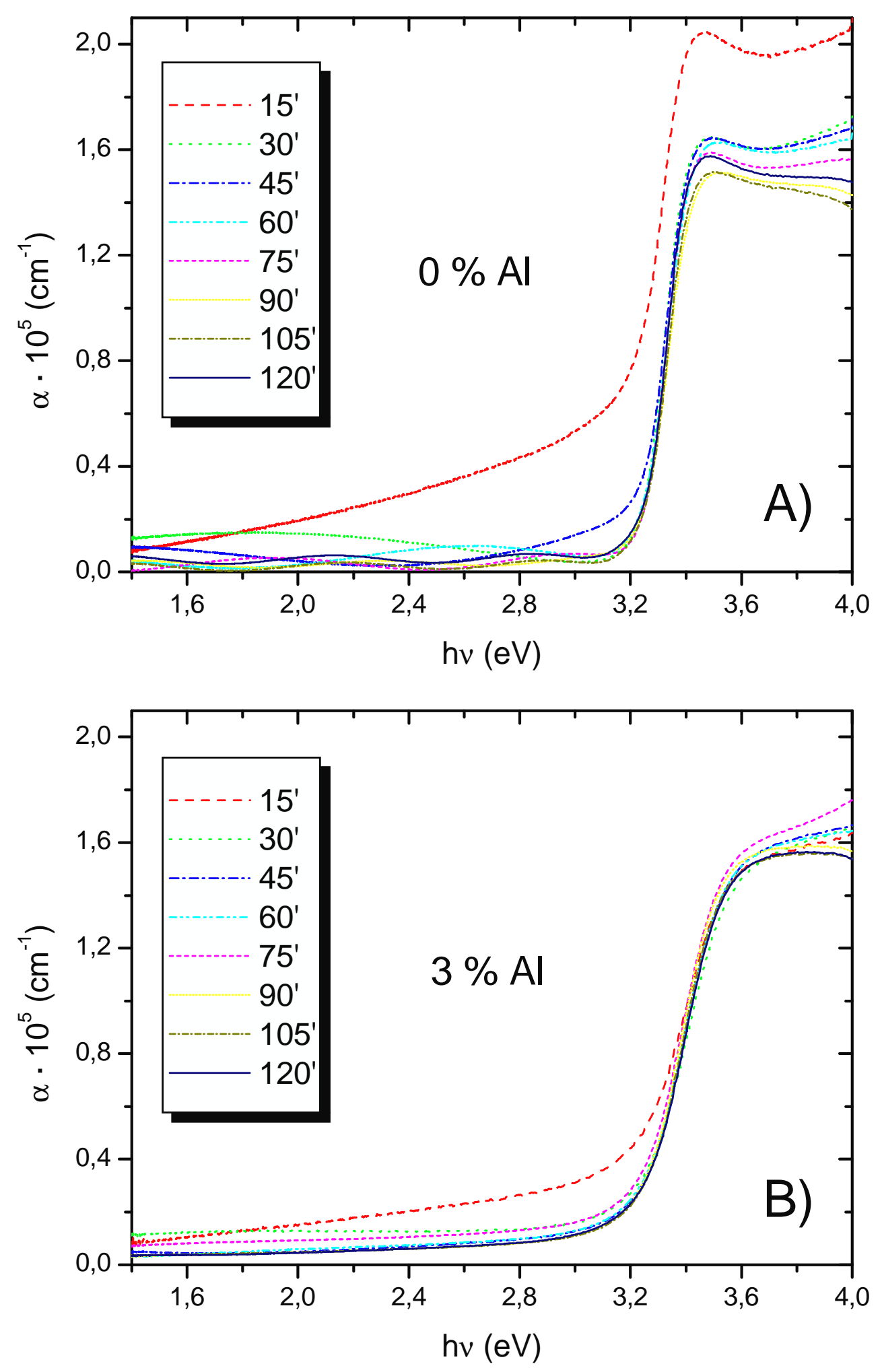

6 


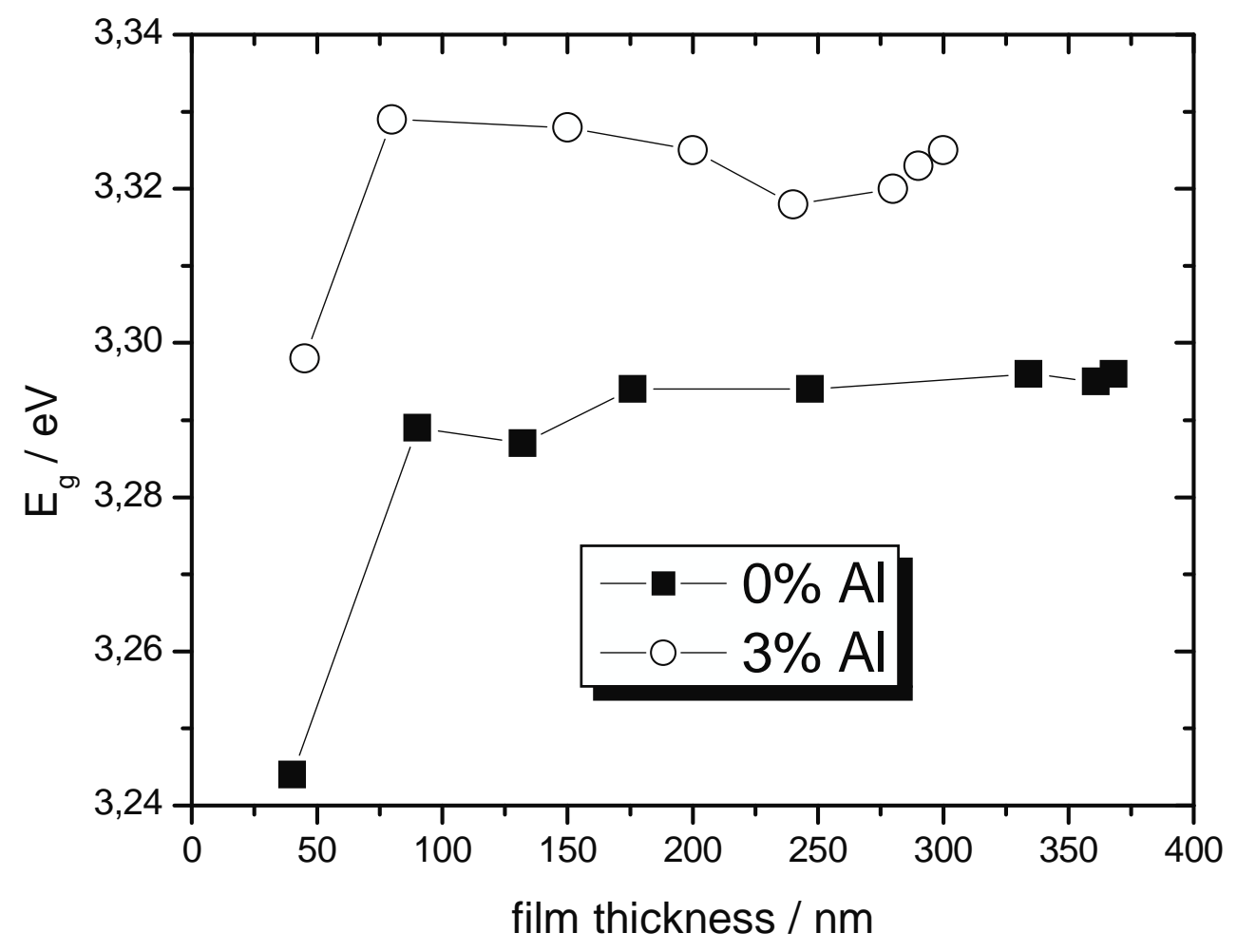




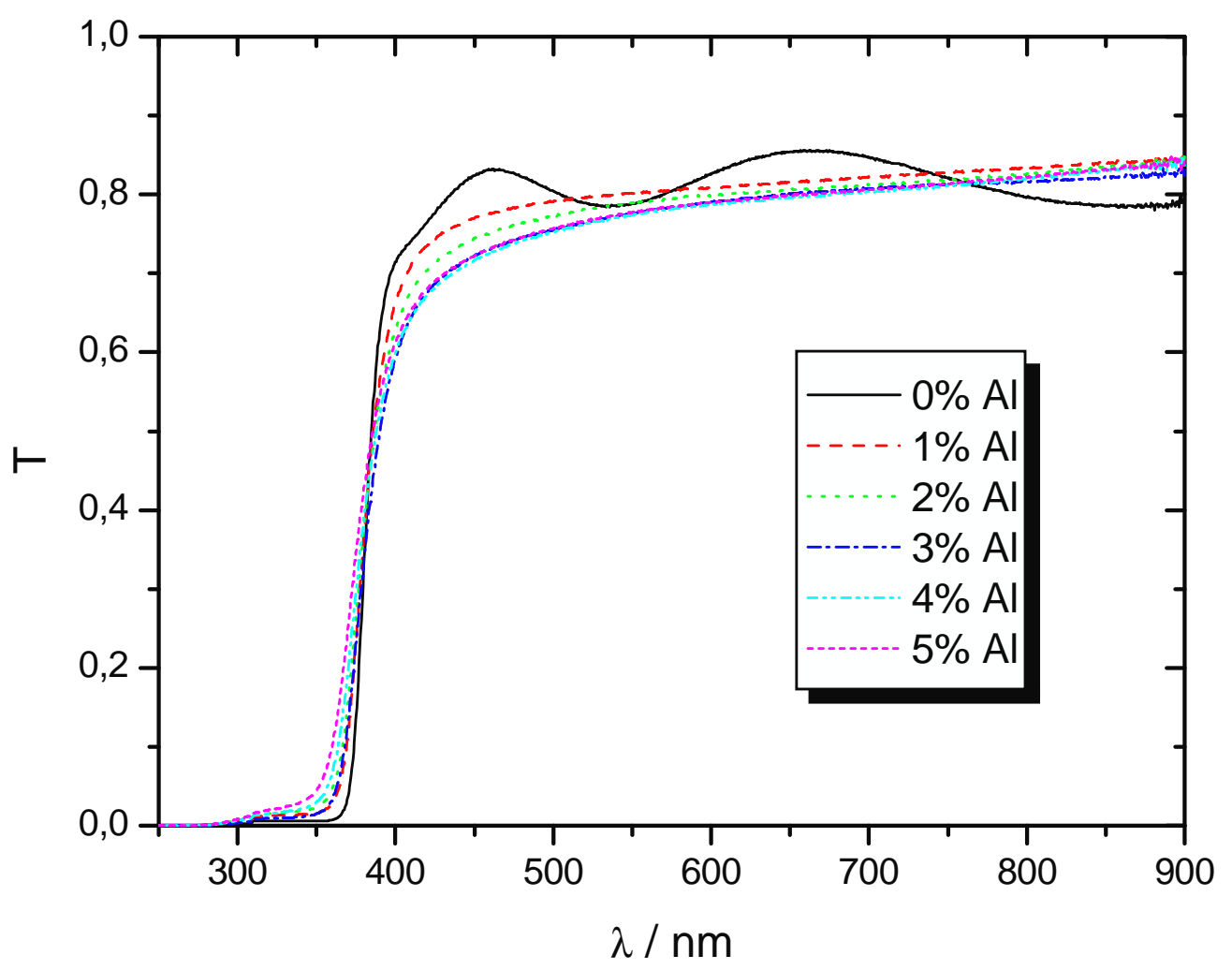

8 


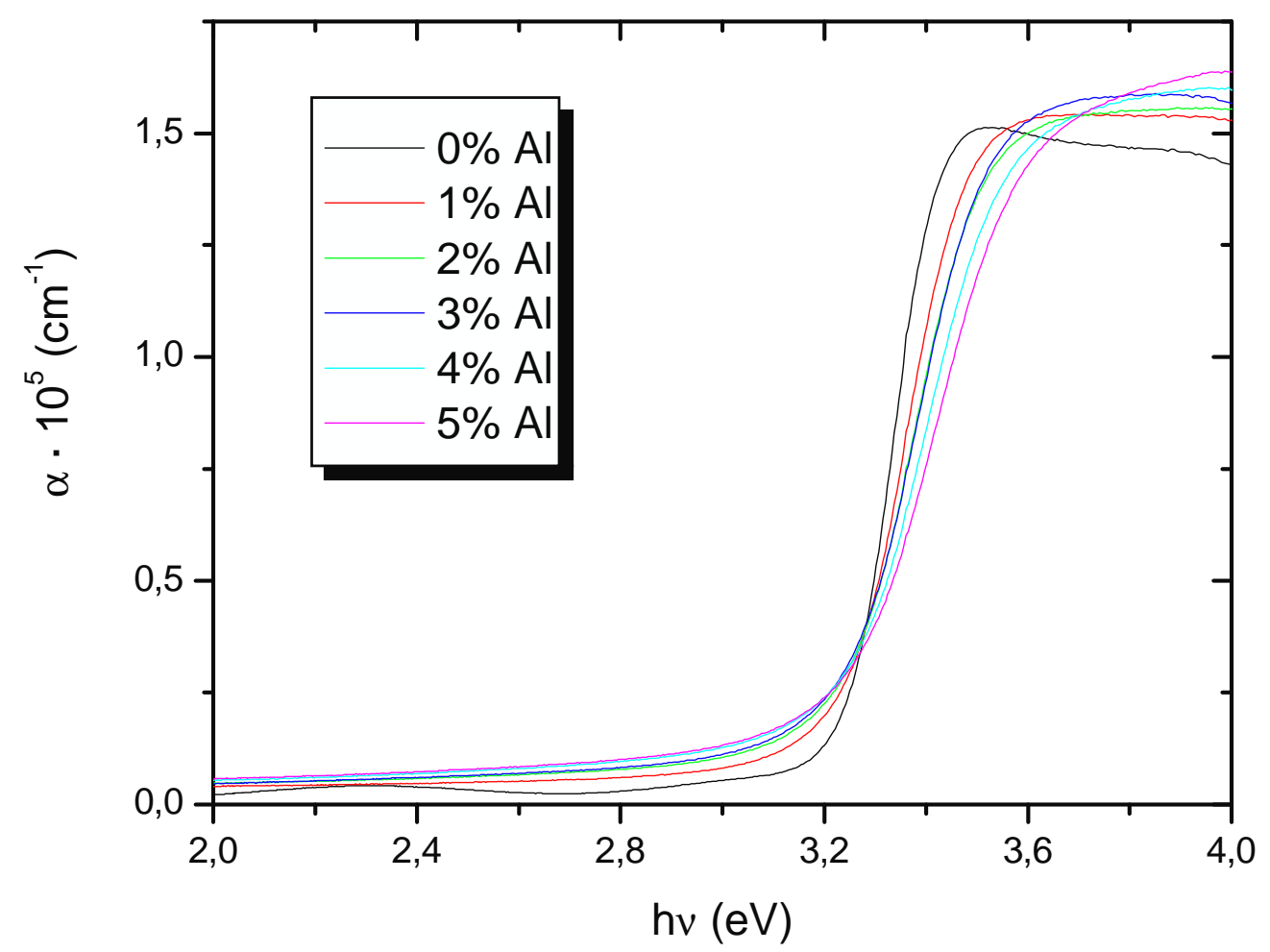

9 
Compositional and optical characterization of $\mathrm{Al}$ doped $\mathrm{ZnO}$ films prepared by $\mathrm{CSP}$

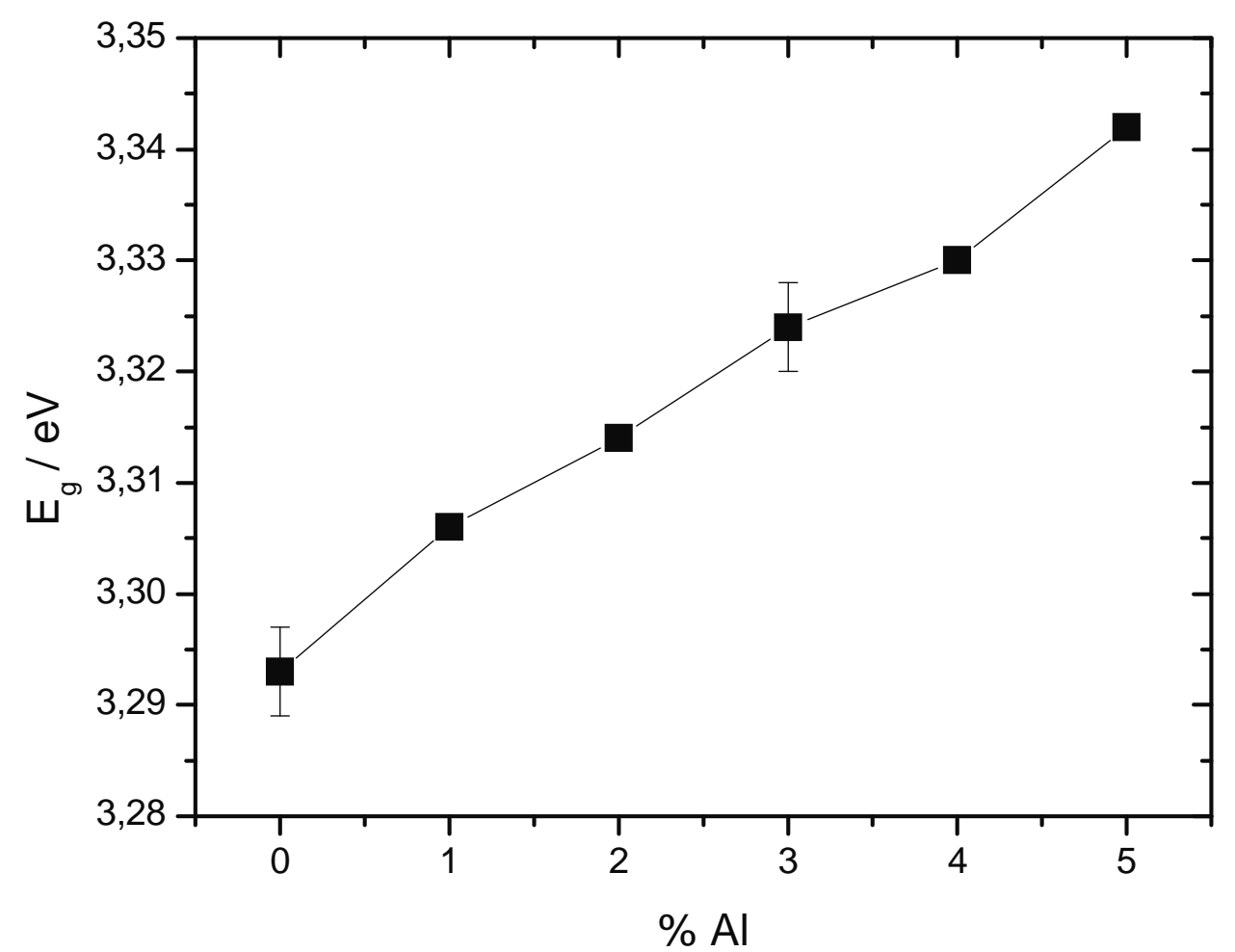

